\begin{tabular}{|c|c|}
\hline \multirow{3}{*}{ 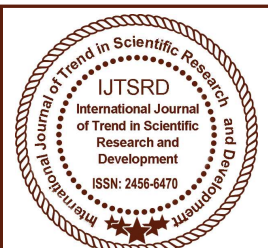 } & \multirow{2}{*}{$\begin{array}{l}\text { International Journal of Trend in Scientific Research and Development (IJTSRD) } \\
\text { International Open Access Journal I www.iitsrd.com }\end{array}$} \\
\hline & \\
\hline & ISSN No: 2456 - 6470 | Volume - 2 | Issue - 6 | Sep-Oct 2018 \\
\hline
\end{tabular}

\title{
Physio-Chemical Analysis of Water Samples Collected from Jummapatti Area, Neral, Maharashtra
}

\author{
Dr. Leena Muralidharan ${ }^{1}$, Dr. Sangeeta Gaur ${ }^{1}$, Chinmay Muralidharan ${ }^{2}$ \\ ${ }^{1}$ V. K. K. Menon College of Commerce and S.S. Dighe College of Science, Mumbai, Maharashtra, India \\ ${ }^{2}$ Thadomalshahani Engineering College, Mumbai, Maharashtra, India
}

\begin{abstract}
Water is a natural resource for human life. Demand for fresh water increased in last decades due to increase in population. The quality of water is affected due to water pollution that has caused an adverse impact on human health. The drinkable water should be of good quality and its study on parameters gives a perfect analysis. The present study was conducted to evaluate the water quality in Jummapatti hill station which is situated at Neral-Matheran route in Maharashtra. "Jummapatti waterfall" is an attractive tourist point. To check the water quality, water sample were collected from different area of Jummapatti. Water quality parameter such as dissolved oxygen, free carbon dioxide, phosphates, total hardness, turbidity, and $\mathrm{pH}$ were measured using standard methods. This research article provides useful information about the current status of the physio-chemical parameters of water quality in Jummapatti, Maharashtra.
\end{abstract}

Keyword: jummapatti hill station, physio-chemical analysis, water quality

\section{INTRODUCTION}

Water is the main component for all living organism. It is very essential for all cells, tissues and organs and work as a building block for them (Lang and Waldegger, 1997; Je'quierl and Constant 2010). The Joint Monitoring Programme (JMP) for Water Supply and Sanitation, implemented by the World Health Organisation (WHO) and UNICEF (2013), reported that 768 million people have no access to safe and drinkable water, out of which $83 \%$ of them belongs to rural areas. According to Meybacket. al., (1996) water quality means "the suitability of water to sustain various uses or processes". Microbiological contamination is a major problem of the quality of the drinking water beside this water can be contaminated by inorganic components (Sorliniet. al., 2013). There are some factors which have adverse effect on water quality such as changes in climate, increased population, and increase requirement of food and energy (Sinhaet al., 2018). The use of quality water is the biggest challenge for $21^{\text {st }}$ century (Sinhaet. al., 2018). Best water quality is essential for everyone as polluted water has adverse effect on health of not only to animals but also to human (Menget. al., 2018). Extreme climate changes also increases the risk of contamination in water (both surface and ground water) (Cross and Latorre, 2015). Decline in water quality is also caused by waste release from human and industries (Gupta et. al., 2017).

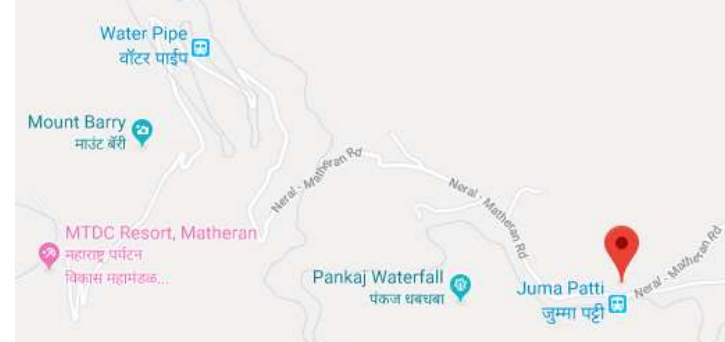

Fig. 1: Map showing study area 


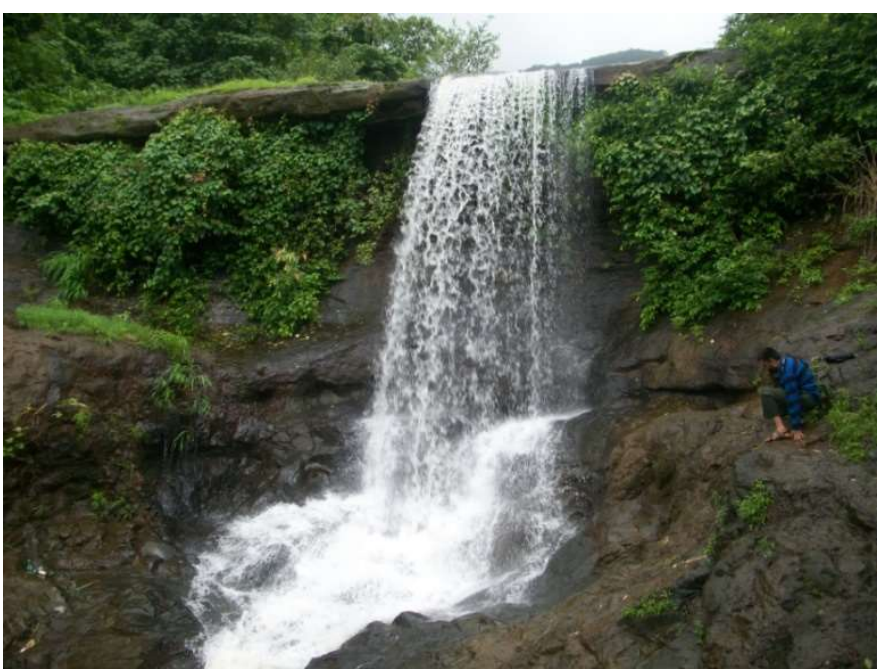

Fig.2: Jummapatti Waterfall

$\mathrm{pH}$ observed in the present study may be due to the decomposition of allochthonous matter and high photosynthetic activity of phytoplankton (Muralidharan and Waghode, 2014; Muralidharanet. al., 2015).

Table 1: Physio-chemical parameters of water samples collected from Jummapatti area

\begin{tabular}{|c|c|}
\hline Quality parameter & Result \\
\hline $\mathrm{pH}$ & 8.5 \\
\hline Temperature & $19^{\circ} \mathrm{C}-29^{\circ} \mathrm{C}$ \\
\hline
\end{tabular}

Table 2: Physio-chemical parameters of water samples collected from Jummapatti area

\begin{tabular}{|c|c|}
\hline Quality parameter & Result(Mean \pm SEM $)$ \\
\hline Dissolved oxygen & $4.95 \mathrm{mg} / \mathrm{l} \pm 0.0021$ \\
\hline Total Hardness & $60.08 \mathrm{mg} / \mathrm{l} \pm 0.025$ \\
\hline Carbon di oxide & $5.055 \mathrm{mg} / \mathrm{l} \pm 0.017$ \\
\hline Phosphate & $1.58 \mathrm{mg} / 1 \pm .0021$ \\
\hline
\end{tabular}

High $\mathrm{pH}$ causes a bitter taste in water, irritation to the eyes, skin, and mucous membrane (WHO, 1996).

In the present investigation temperature of water recorded was $19{ }^{\circ} \mathrm{C}$ to $29{ }^{\circ} \mathrm{C}$ (Table 1). According to Cross and Latorre (2015) climate changes induces the high water temperature, which is related to reduction in dissolved oxygen in water. The present observations have been true for several water bodies in India (Narayanaet. al.,2008; Garget. al., 2009; Vermaet. al., 2011; Prabhakeret. al., 2012 and Meenakshi saxena, 2012). According to Koliyar and Rokade (2008) water temperature shows a variation with atmospheric temperature.

In the present study water sample were taken from different locations of Jumaapatti hill station, Maharashtra (Fig.1, 2 and 3). The water quality parameters such as dissolved oxygen, $\mathrm{pH}$, temperature, total hardness and phosphate were measured. Standard methods (APHA, 2005) were used for the analysis.

\section{Result and discussion:}

$\mathrm{pH}$ is the basic measurement for water quality, it tell us the acidic or basic nature of water. In the present study $\mathrm{pH}$ recorded was 8.5 (Table 1) which shows the alkaline nature of the water sample collected from Jummapatti area. A pH range of 6.0 to 9.0 appears to provide protection for the life of fresh water fish and bottom dwelling invertebrates (Kumar and Puri, 2012; Muralidharan and Waghode, 2014; Muralidharanet. al., 2015). The $\mathrm{pH}$ of safe water ranges between 6.5 to 8.0 and this $\mathrm{pH}$ is dependent on the source of water, soil type, contaminants in water (Kale, 2016). High

Dissolved oxygen was recorded in the present work was $4.96 \mathrm{mg} / \mathrm{l}($ Table 2). It reflects the amount of gaseous oxygen dissolved in water. Low dissolved oxygen content shows the anaerobic conditions in water (Koliyar and Rokade, 2008). In the present study low dissolved oxygen may be due to run over of water which carry many suspended solid compounds such as bacteria, hydrocarbons, heavy metal and suspended solids. These components can interrupt the sun light to enter in to the water. This interruption may induce the reduction of the oxygen level in water. This is also supported by Chine duet. al.,(2011). Koliyar and Rokade (2008) suggested that low quantity of dissolved oxygen in water is a indicator for low production of primary aquatic ecosystem. 
Hardness of water represent the dissolved minerals in water i.e. calcium and magnesium (WHO, 2009; Sengupta, 2013; Muralidharan and Waghode, 2014). Total hardness of Jummapatti water sample recorded was $60.12 \mathrm{mg} / \mathrm{l}$ (Table 2) can also affect the osmo regulation in fishes (Chineduet. al., 2011). High value of hardness in drinking water can cause laxative effects (Sengupta, 2013; Akram and Fazal-urRehman, 2018).Jummapatti water sample adjudged as soft water throughout the study (Sawyer 1960). According to Das, (1996) the optimum hardness for fish production was found to be around 75 to 150 $\mathrm{mg} / \mathrm{l}$.

In the present study carbon dioxide content in Jummapatti water sample recorded was $5.09 \mathrm{mg} / 1$ (Table 2). This low value of $\mathrm{CO}_{2}$ may be attributed to high level of $\mathrm{pH}$ in present research work.

The phosphate level content in the sample water was $1.59 \mathrm{mg} / \mathrm{l}$ observed (Table 2), may be due to precipitation, animal wastes, fertilizers, and land runoff (Holt et. al., 1970), weathering of phosphorus bearing rocks or leaching from soils of nearby catchment areas (Muralidharan and Waghode2014). The recommended value of phosphorus in drinking water according to EPA $5 \mathrm{mg} / \mathrm{l}$ (Singh, 2016).According to Kumar and Puri (2012) phosphate can exist in water as particles or as aquatic organisms. They also suggested that in normal condition phosphate does not have any adverse effect but the high level of it can cause digestive problems.

\section{Conclusion:}

Water quality is affected by various human and natural activities. Our study indicates that water collected from Jummapattihill station has high level of $\mathrm{pH}$, phosphate and hardness whereas the low amount of dissolved oxygen, and $\mathrm{CO}_{2}$ was recorded. Jummapatti water sample can be placed under alkalliphious and entropic water body (Lee et. al., 1981). High fish production can be expected from this area as a phosphorous contain is above $0.02 \mathrm{mg} / \mathrm{l}$. During our study we found that garbage's, water bottle, dry and wet waste are dumped by tourist in Jummapatti waterfall area which can add to the reason of pollution and can prove to be harmful for the ecosystem. Sensitive measure must be taken through proper planning towards this nature gifted wet land. Awareness has to be created regarding the importance of Jummapatti for common public and concern authorities. From the present study, it can be concluded that to minimize the water related problems the quality of water should be checked regularly. To avoid water pollution waste materials and garbage dumping should be prohibited in the study area.

\section{References:}

1. APHA, AWWA, and WEF (2005): Standard methods for the examination of water and waste water. $21^{\text {st }}$ edition, Washington, DC.

2. Akram S. and Fazal-ur-Rehman (2018): Hardness in drinking-water, its sources, its effects on humans and its household treatment. . J. Chem. Applications.,4:1-4

3. Chinedu S. N., Nwinyi O. C., Oluwadamisi A. Y. and Eze V. N. (2011): Assessment of water quality in Canaan land, Ota, Southwest Nigeria. Agric. Biol. J. N. Am., 2:577-583

4. Cross K. and Latorre C. (2015): Which water for which use? Exploring water quality instruments in the context of a changing climate. Aquatic Procedia 5: 104-110

5. Das R. K. (1996): Monitoring of water quality, its importance in disease control. Proceeding of national workshop on fish and prawn disease, Epizootics and quarantine adoption in India at central England Fisheries Research Institute, Barrackpore, pp. 51-54

6. Garg R. K., Rao R. J. and Saksena D. N. (2009): Water quality and conservation management of Ramsagar reservoir, Datia, Madhya Pradesh. J. Envion. Biol., 30: 909-916.

7. Gupta N., Pandey P. and Hussain J. (2017): Effect of physicochemical and biological parameters on the quality of river water of Narmada, Madhya Pradesh, India. Water Science 31:11-23

8. Holt R. F., Timmons D. R. and Joseph J. L. (1970): Accumulation of phosphate in water. J. Agric. Food Chem., 18:781-784

9. Je'quierl E. and Constant F. (2010): Water as an essential nutrient: The physiological basis of hydration. Eur. J.Clin.Nutr.,64: 115-123

10. Kale S. V. (2016): Consequence of temperature, $\mathrm{pH}$, turbidity and dissolved oxygen water quality parameters. IARJST. 3:196-190

11. Koliyar J. G. and Rokade N. S. (2008): Water quality in Powailake: Mumbai, Maharashtra. Sengupta, M. and Dalwani, R. (Editors). 2008 
Proceedings of Taal2007: The 12th World Lake Conference: 1655-1659

12. Kumar M. and Puri A. (2012): A review of permissible limits of drinking water. Indian $\mathrm{J}$. Occup. Environ. Med., 16:40-44

13. Lang F. and Waldegger S. (1997): Regulating cell volume. Am. Scientist, 85: 456-463

14. Lee G. F., Jones R. A. and Rast W. (1981): Alternative approach to trophic state classification for water quality management. Occ. Pap.No.66, Dept. Civil Environ. Engg.Prog., Colorado State University, Fort Collins, Colorado.

15. Meng N., Ju-lin Y., Mei L. and Zhi-min G. (2018): Assessment of water quality and phytoplankton community of Limpenaeusvannamei pond in intertidal zone of Hangzhou Bay, China. Aquaculture Reports 11:53-58

16. Meybeck M., Kuusisto E., Mäkelä A. and Mälkki E. (1996): Water quality monitoring - A practical guide to the design and implementation of freshwater quality studies and monitoring programmes. United Nations Environment Programme and the World Health Organization (C) 1996 UNEP/WHO. ISBN 0419223207 (Hbk) 0 419217304 (Pbk)

17. Muralidharan L., Oza A. and Singh A. (2015): Study on physio-chemical analysis of heavily polluted ShivajiTalao and its impact on aquatic bodies. World J. Clin. Pharmacol. Micrbiol. Toxicol., 1:27-31

18. Muralidharan L. and Waghode S. (2014): Studies on physico-chemical characteristics of Tawa and Halalireservior of Bhopal, India. Int. J.Curr. Sci., 11:E 70-83

19. Narayana J., Puttaiah, E. T. and Basavaraja D. (2008): Water quality characteristics of Anjanapur reservoir near Shikaripur, District Shimoga, Karnatka. J. Aqua. Biol., 23: 59-63

20. Omezuruike O. I., Damilola A. O., Adeola O. T., Fajobi, Enobong and Olufunke S. (2008): Microbiological and physicochemical analysis of different water samples used for domestic purposes in Abeokuta and Ojota, Lagos State, Nigeria. Afr. J. Biotechnol., 7:617-621

21. Prabhaker C., Saleshrani K., Tharmaraj K. and Kumar V. M. (2012): Seaonal variation in hydrological parameters of Krishnagiridam,
Krishnagiri district, Tamil Nadu, India. Intern. J. Pharmacol. Biol. Archives, 3:134-139.

22. Sawyer C. H. (1960): Chemistry for sanitary engineers. McGraw Hill Book Company, New York

23. Saxena M. and Saxena D. N.(2012):Water quality and tropic status of Raipur resorvior in Gwalior, Madhya Pradesh. J. Natur. Scie. Res., vol. 2, No. 8

24. Sengupta P. (2013): Potential health impacts of hard water. Int. J. Prev. Med., 4:866-875

25. Sinha K., Srivastava D. K. and Bhatnagar R. (2018): Water quality management through data driven intelligence system in Barmer region, Rajasthan. Proc. Comp. Sci., 132:314-322

26. Singh A. L. (2016): Nitrate and phosphate contamination in water and possible remedial measures. Environmental Problems and Plants. Editor, DwivediN.pp 45-56

27. Sorlini S., Palazzini D., Sieliechi J. M. and Ngassoum M. B. (2013): Assessment of physicalchemical drinking water quality in the Logone Valley (Chad-Cameroon). Sustainability, 5: 30603076

28. Verma P., Chandawat D. K. and Solanki H A. (2011): Seasonal variation in physic-chemical and phytoplankton analysis of Kankaria Lake, Ahmedabad. Life Sci. Leaflets. 19:842-854

29. WHO (1996): Guidelines for drinking-water quality, 2nd ed. Vol. 2. Health criteria and other supporting information. World Health Organization, Geneva, 1996

30. WHO (2009): Calcium and magnesium in drinking-water public health significance. WHO Library Cataloguing-in-Publication Data .ISBN 9789241563550 .

31. WHO; UNICEF. Progress on sanitation and drinking water (2013):2013 Update; World Health Organisation/UNICEF: Geneva, Switzerland, 2013. 